\title{
Dental Corrosion in Preindustrial Societies: A Case Study of a Child from "Pedra do Cachorro" Dating to 1,470 BP, Northeastern Brazil
}

\author{
Rodrigo Elias Oliveira ${ }^{1 *}$, Ana Solari ${ }^{2}$, Sergio Francisco S.M. Silva², Gabriela Martin ${ }^{2}$, \\ Caio Belem Soares ${ }^{2}$, and Andre Strauss ${ }^{1}$ \\ ${ }^{1}$ Universidade de São Paulo, Brazil \\ ${ }^{2}$ Universidade Federal de Pernambuco, Brazil
}

Keywords: dental wear, paleopathology, gastroesophageal reflux, dental corrosion, dental erosion

\begin{abstract}
Reflux, frequent vomiting, and the high intake of acidic beverages in industrial societies result in a relatively elevated frequency of dental corrosion. In the past, however, chemical dental wear was rather rare. Here we present and analyze a child from the Fifth Century CE that evidenced a growth pattern which was below that expected for an infant of its age. Furthermore, the child also had a peculiar pattern of dental erosion. This 3-year-old child dated to 1470 $\pm 30 \mathrm{BP}$ from the archaeological site of Pedra do Cachorro (northeastern Brazil) had its bones and teeth analyzed macroscopically, radiographically (X-ray and tomography), and microscopically (SEM). Harris lines, linear enamel hypoplasia, and the poor linear growth presented by this sub-adult suggest malnutrition or some other physiological stress. The unique pattern of chemical wear on the lingual surfaces of upper incisors was compatible with dental corrosion, reinforcing the diagnosis of frequent vomiting possibly caused by an undefined gastric disorder, which could have been a factor in the early death of this child.
\end{abstract}

Built from the hardest tissues found in the human food bolus being forced against these surfaces by body (enamel and dentin) teeth are commonly pre- the tongue, cheeks, and lips (Grippo et al., 2012).

served in the archaeological record. Dental wear These two processes are strongly associated has long been studied as an important source of with the masticatory cycles responsible for the fordata regarding a broad spectrum of past and pre- mation of occlusal wear. The severity of occlusal sent human activities (d'Incau et al., 2012; Deter, wear increases during the lifetime of an individual 2009; Smith, 1984; Turner and Machado, 1983). and can therefore be used as a proxy for estimating Dental wear is the result of the non-carious loss of age-at-death (Prince et al., 2008). As abrasion is a dental tissues due to the additive effects of me- direct result of the size and roughness of the inchanical and chemical processes (Brace and gested particles; the severity of occlusal wear can Molnar, 1967; Molnar, 2008; Oliveira and Neves, also be used in reconstructing dietary habits 2015; Van't Spijker et al., 2009).

It is used to classify tooth surface loss due to attrition, abrasion, abfraction, and corrosion, depending on the nature of the wasting process. In this sense, "attrition" is a type of dental wear caused by tooth-to-tooth friction that occurs during chewing, clenching, and deglutition. This type of tooth surface lesion affects the occlusal/incisal areas, as well as the proximal surfaces (Smith, 1984).

"Abrasion" is the result of friction between teeth and exogenous agents such as food (e.g. fruits, leaves, vegetables, shells, and bones) and exogenous particles in the food bolus (e.g. sand, stone, and charcoal). During mastication, lingual and buccal/facial surfaces can be worn down by the (Grippo et al., 2012; Scheid and Weiss, 2012).

Deviations from the typical erosion patterns resulting from attrition/abrasion masticatory occlusal wear are indicative of pathological conditions or paramasticatory habits. Some nonphysiological activities can also change dental structure. Among others, parafunctional habits

*Correspondence to:

Rodrigo Elias Oliveira

Instituto de Biociências \& Faculdade de

Odontologia

Universidade de São Paulo

eliaso@alumni.usp.br 
such as clenching and grinding of teeth (bruxism) are very common in modern societies, and might be directly associated to psychosocial problems (Carlsson et al., 2003; Manfredini and Lobbezoo, 2009; Pavone, 1985). However, the most common parafunctional activity observed in preindustrial and traditional societies is the use of teeth as tearing and grabbing tools, also called Lingual Surface Attrition of the Maxillary Anterior Teeth (LSAMAT) when these lesions are present on upper incisors (Irish and Turner, 1987; Larsen et al., 1998; Waters-Rist et al., 2010).

"Abfraction" is a less frequent type of mechanical dental wear observed on archaeological skeletons. Although the precise etiology is still a matter for debate, abfraction is broadly considered to reflect stress concentration on the cervical region of teeth, as a result of excessive cyclic loading (Lanigan and Bartlett, 2013; Lucas and Omar, 2012; Oliveira, 2014). Most likely this excessive loading is a consequence of parafunctional use of the masticatory apparatus.

While mechanical wear is commonly reported in archaeological contexts, chemical wearing is rare in preindustrial societies. "Corrosion" or "biocorrosion" are the terms used to define the chemical dissolution of teeth surfaces. Corrosion/ biocorrosion can be divided into four (4) separate categories: exogenous, endogenous, proteolysis (degradation of the small amount of enamel protein in the caries process), and electrochemical (as the result of piezoelectric effects only on dentin, not on enamel) (Grippo et al., 2012). Nevertheless, in an archaeological context we usually find, and therefore discuss, exogenous and endogenous corrosion.

Corrosion happens when the dental surface is exposed to an acidic agent capable of creating a microenvironment with a constant $\mathrm{pH}$ of below 4.0 (Dong et al., 1999; Hillson, 2008; Järvinen et al., 1991; Scheid and Weiss, 2012). The solubilization of hydroxyapatite, the mineral structure of enamel, dentin, cementum, and bone, occurs when the local $\mathrm{pH}$ is 5.5 or below, whereas the critical $\mathrm{pH}$ for solubilization of fluorapatite is 4.5 or below (Ekstrand and Oliveby, 1999). Microbial biocorrosion or simply dental caries is the most common human pathological condition observed on archaeological skeletons. Dental caries is caused by the dissolution of the tooth surface due to the lactic acid produced by cariogenic bacteria (Larsen, 2008; Morimoto et al., 2014).

In contrast to the archaeological record, exogenous or endogenous corrosion (formerly known as "dental erosion") is more common in industrial societies (Robb et al., 1991a, 1991b). The elevated consumption of liquids with a $\mathrm{pH}$ below 3.0, such as carbonated beverages and citrus juice is most likely a major cause of the exogenous corrosion (Eccles and Jenkins, 1974; Honório et al., 2008; Järvinen et al., 1991; Lussi et al., 2011).

Among the "endogenous corrosions", gastroesophageal reflux disease (GERD) is a potential cause, given that it brings up extremely acidic gastric fluids to the mouth, and therefore in direct contact with dentition (Bartlett et al., 2013; Gudmundsson et al., 1995). Similarly, dental corrosion can be associated with bulimia and other eating disorders that involve systemic and recurrent vomiting (Gudmundsson et al., 1995; Lazarchik and Filler, 2000; Moazzez et al., 2004).

There are many case reports on dental corrosion in the archaeological literature, with most of them presenting dietary erosive wear with or without associated attrition as shown by Coupal and Soltysiak (2017). However, it is very rare to see cases in which the dental corrosion was caused by frequent regurgitation (Robb et al, 1991a; Coupal and Soltysiak, 2017).

In this article, we describe the case of a 3-yearold child radiometrically dated to $1,470 \pm 30 \mathrm{BP}$, that was exhumed from an archaeological site located in northeastern Brazil. This child presents a unique pattern of chemical wear that was compatible with dental corrosion. We then compared this observation, against a broader characterization of oral health, including caries, periapical lesions, dental calculus, and periodontal bone resorption (Guatelli-Steinberg et al., 2004; Hillson, 2008; Oliveira and Neves, 2015). Osteological markers of physiological imperilments, such as linear enamel hypoplasia (LEH) and transverse radiopaque lines (Harris lines) were also considered.

\section{Burial 2 from Pedra do Cachorro}

The skeleton analyzed in this study - Burial 2 was uncovered in 2015 at the Pedra do Cachorro archaeological site, located in the Parque Nacional do Catimbau, Pernambuco, Brazil (Figure 1). This site is located in the sheltered area formed along the side of a large sandstone outcrop. The region presents an important archaeological record for the presence of prehistoric foraging groups, dating from 6,000 years before the present, onwards. Between 2015 and 2016, four field campaigns were undertaken at the site, resulting in the excavation of a $68 \mathrm{~m}^{2}$ area. Two other burials, directly dated to $760 \pm 30$ and 3,560 \pm 30 years BP respectively, were 


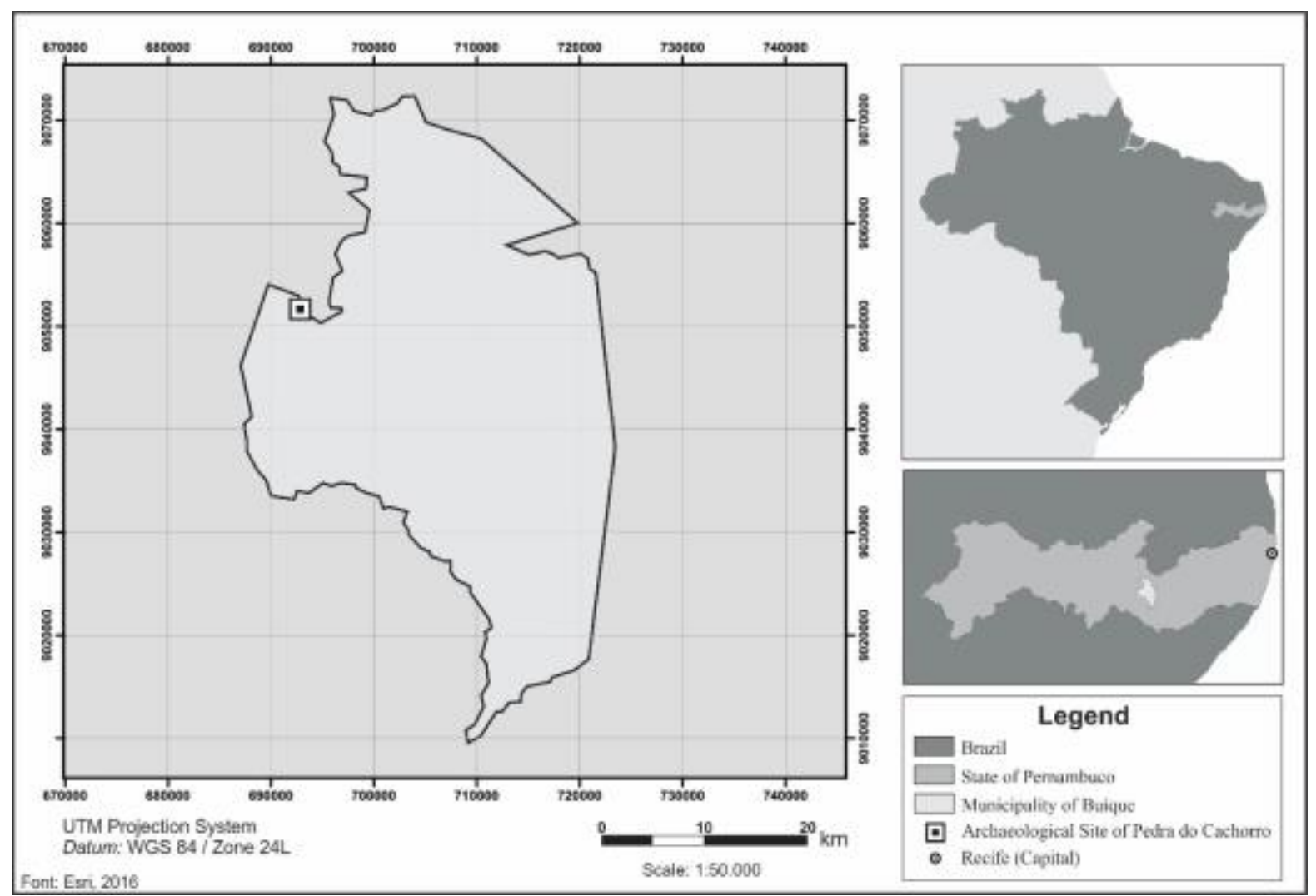

Figure 1. Location of the archaeological site of Pedra do Cachorro, Buíque - Pernambuco, Brazil.

also found in Pedra do Cachorro but they are not pit was filled with loose red-brown sediment part of the present article (Solari et al., 2015,;2016). whose current $\mathrm{pH}$ was determined to be $6.64-7.15$

Burial 2 contains the skeleton of a young child (Silva et al., 2019). The reddish color of the external found within an oval pit $35 \mathrm{~cm}$ width; $92 \mathrm{~cm}$ long; surface of the human bones most likely resulted $20 \mathrm{~cm}$ deep) surrounded by sandstone blocks. The from long exposure to the burial sediment as no burial did not contain grave goods. A rib fragment evidence for ochre was identified (Figure 3). Charfrom Burial 2 was directly dated to 1,470 $\pm 30 \mathrm{BP}$ coal fragments were found amidst the human (Beta 447238). The bone distribution indicates that bones and surrounding sediments. One charcoal the body was deposited in a prone position with piece was dated to 2,100 \pm 30 years BP, indicating flexed legs (Figure 2) (Solari et al., 2016). The burial that it was not contemporaneous with Burial 2.
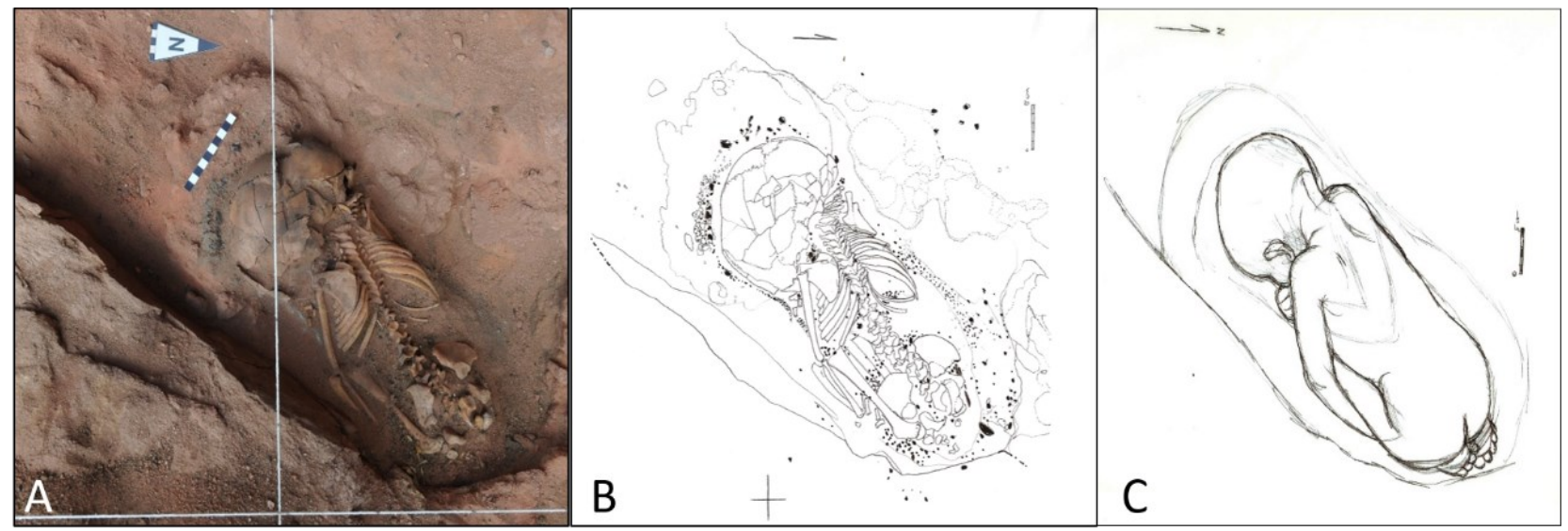

Figure 2. Burial 2 of Pedra do Cachorro: photograph of the exhumation (A), burial sketch (B), graphic reconstruction of the original burial position (C). 
This observation was compatible with the lack of of its root and crown (Figure 4). The resulting maany macroscopic signs of thermal modification on turity index was 15.0 indicating an estimated agethe bones.

Age-at-death was estimated using two different nate sex (Table 2).

methods: linear measurements of long bones and Based on the greater sciatic notch morphology dental development. The length of the limb bones (Cunninghan et al., 2016; Schutkowski, 1993; Uband clavicle indicated an age-at-death of between elaker, 1989), the skeleton was interpreted to be 1.5 and 3 years, respectively (Table 1). Dental de- that of a female - although caution is required givvelopment was assessed using radiographic imag- en that the application of this method to the skelees generated with "Cone Beam Computed Tomog- tal remains of young children is associated with raphy" (CBCT). Following Demirjian et al. (1973) high levels of uncertainty (Mays and Cox, 2000). each remaining permanent tooth in the mandible was scored according to the incremental formation

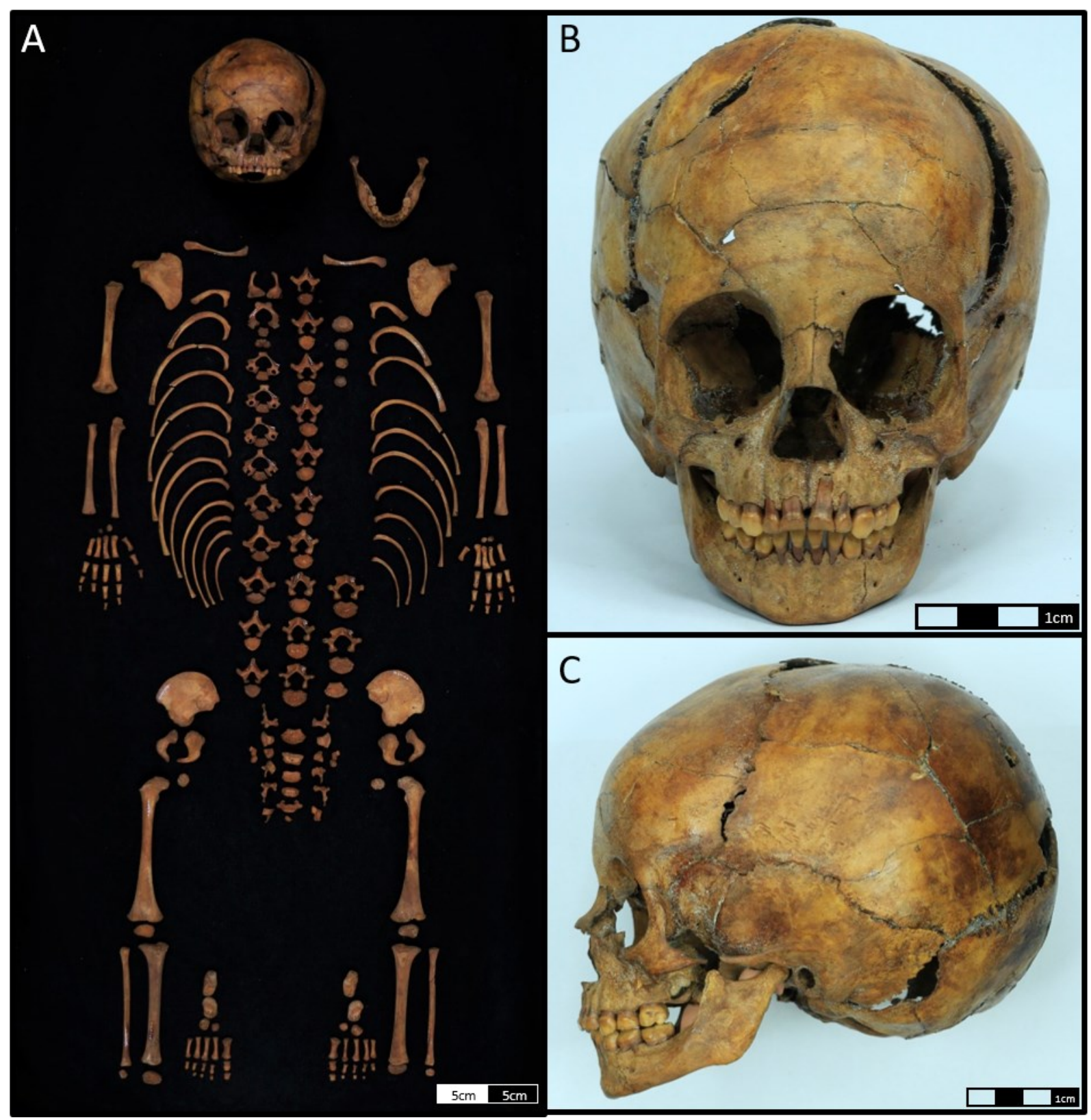

Figure 3. The complete child skeleton, showcasing its excellent preservation (A), anterior (B), and lateral (C) view of the cranium from Burial 2. 
Table 1. Age estimation based on bone length of Burial 2.

\begin{tabular}{cccc}
\hline Bone & $\begin{array}{c}\text { Maximum Length } \\
\text { (mm) }\end{array}$ & $\begin{array}{c}\text { Estimated Age } \\
\text { (years) }\end{array}$ & References \\
\hline Femur L & 147.2 & 1.5 & Maresh, 1970 \\
Femur R & 146.7 & 1.5 & Maresh, 1970 \\
Tibia L & 121.9 & 1.5 & Gindhart, 1973; Maresh, 1970 \\
Tibia R & 120.7 & 1.5 & Gindhart, 1973 \\
Fibula L & 118.9 & 1.5 & Maresh, 1970 \\
Fibula R & 120.4 & 1.5 & Maresh, 1970 \\
Humerus L & 111.7 & 1.5 & Maresh, 1970 \\
Humerus R & 110.9 & 1.5 & Maresh, 1970 \\
Ulna L & 100.9 & 1.5 & Maresh, 1970 \\
Ulna R & 99.5 & 1.5 & Maresh, 1970 \\
Radius L & 92.2 & 1.5 & Maresh, 1970 \\
Radius R & & & Gindhart, 1973 \\
Clavicle L & 91.3 & 1.5 & Maresh, 1970 \\
Clavicle R & 66.0 & 2 to 3 & Gindhart, 1973 \\
& 64.9 & 2 to 3 & Maresh, 1970 \\
& & & Black and Scheuer, 1996 Scheuer, 1996 \\
\hline
\end{tabular}

Table 2. Age estimation based on the maturity, based on the specimen being a female individual (Demirjian et al., 1973).

\begin{tabular}{cc}
\hline Developing Teeth & Demirjian's dental score \\
\hline First molar (M1) & $\mathrm{D} / 8$ \\
Canine (C) & $\mathrm{D} / 3.8$ \\
Lateral incisor (I2) & $\mathrm{D} / 3.2$ \\
Central incisor (I1) & $\mathrm{D} / 0$ \\
\hline \multicolumn{2}{c}{ Maturity index: M1 + C + I2 + I1 = 15.0 } \\
\hline
\end{tabular}

\section{Health Indicators}

The fully erupted deciduous dentition lacks any signs of periapical lesions, linear enamel hypoplasia (LEH), dental calculus, or periodontal bone resorption under macroscopic observation (for methods used to analyze all pathological conditions of the dentition, see Oliveira and Neves, 2015). The only pathological conditions in the deciduous dentition were superficial dental caries lesions in the buccal surface of the cementoenamel

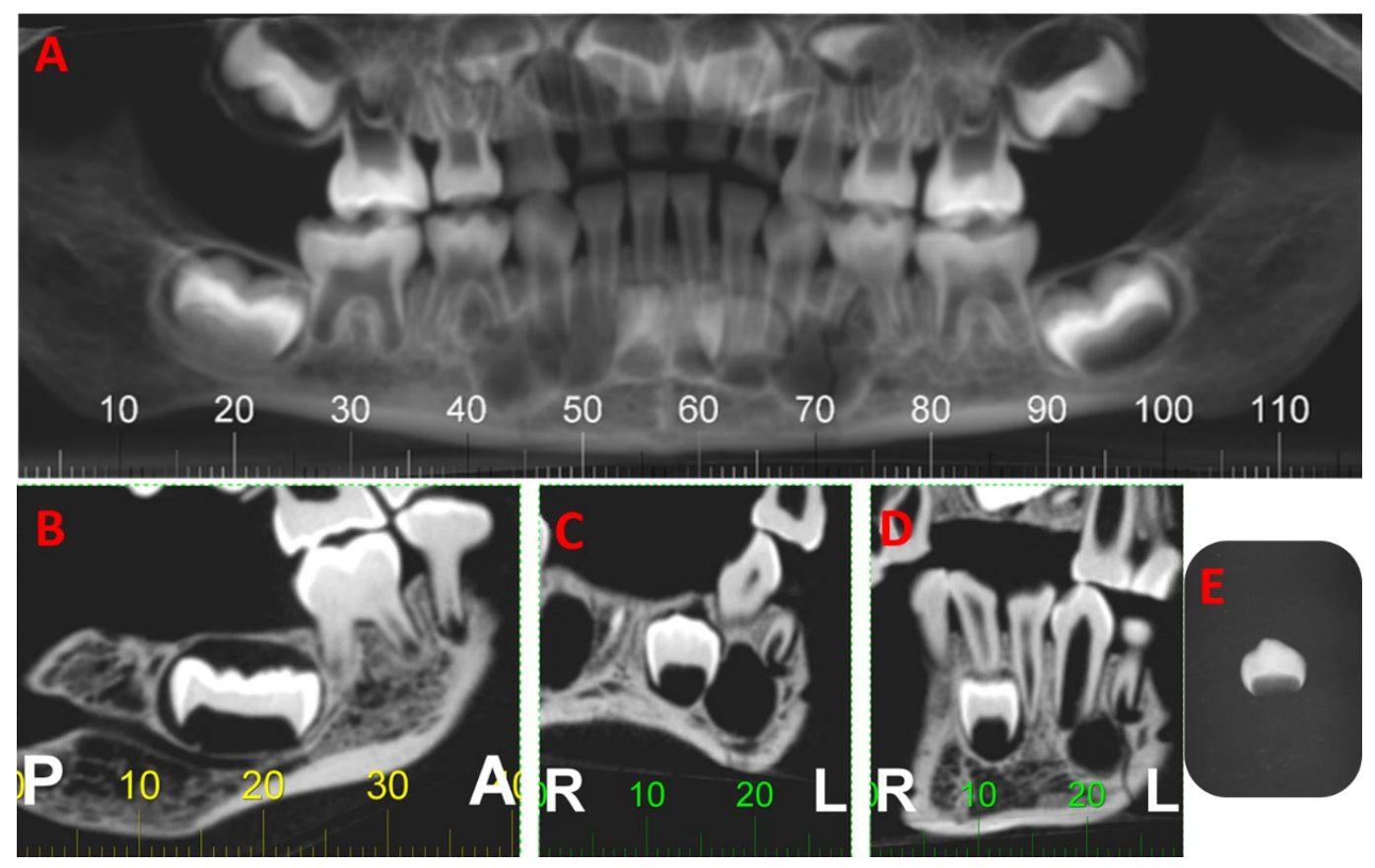

Figure 4. Panoramic reconstruction of the maxillae and the mandible (A). The coronal views (CBCT) of the developing mandibular teeth: left first molar - $\mathrm{LM}_{1}(\mathbf{B})$; left lateral incisor - $\mathrm{LI}_{2}(\mathbf{C})$; left central incisor $-\mathrm{LI}_{1}(\mathbf{D})$; X-ray image from left canine $-\mathrm{LC}_{1}(\mathrm{E})$. 


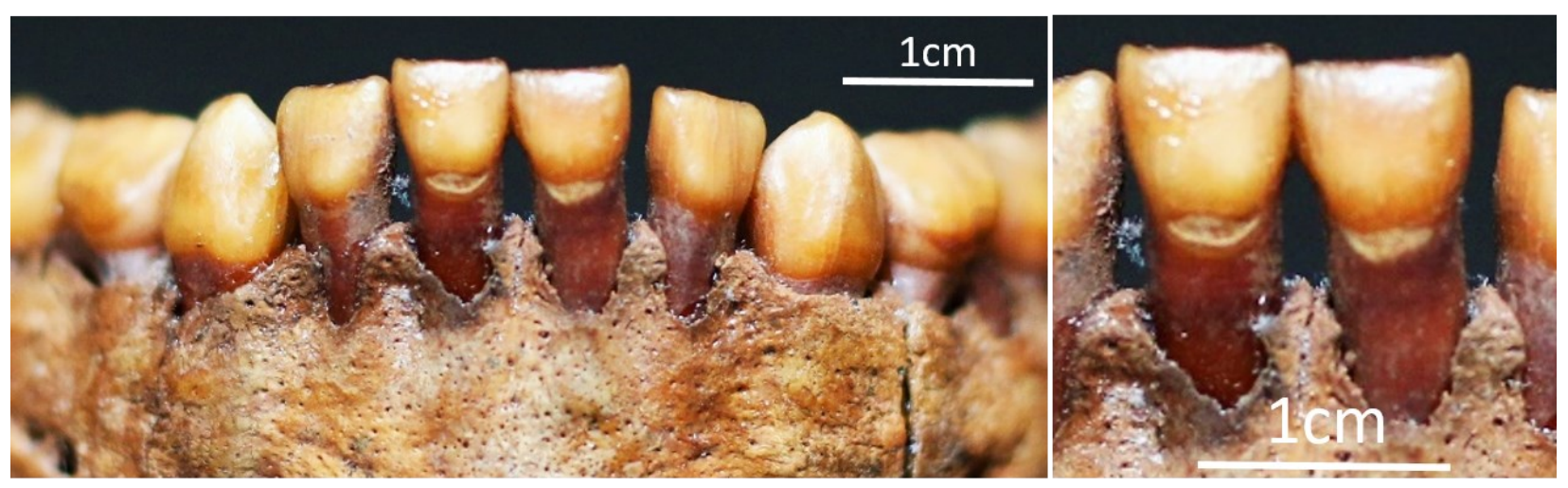

Figure 5. Buccal view from mandibular teeth from Burial 2 with two dental caries in CEJ of right and left central incisors.

junction of the lower central incisors (Figure 5). The irregular border and rough surface of these cavities, despite being located in the cementoenamel junction, distinguish them from abfraction lesions (Nascimento et al., 2016). The permanent canine $\left(\mathrm{LC}_{1}\right)$ presents linear enamel hypoplasia (Figure 6) and an analysis of the long bones using radiographic images revealed the existence of Harris lines along the femora and tibiae (Mays, 1995) (Figure 7).

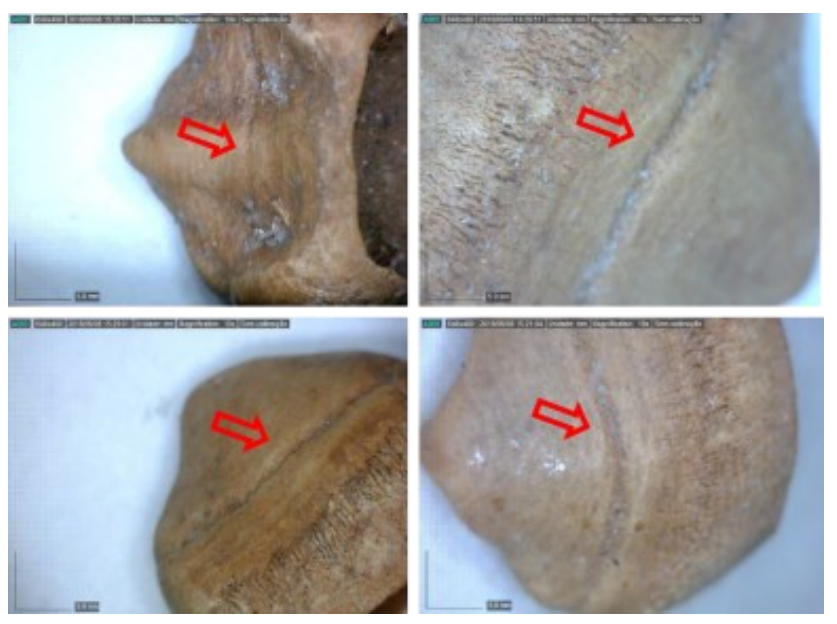

Figure 6. Permanent canine of Burial 2 presenting linear enamel hypoplasia (red arrow).

\section{Dental Wear}

The upper incisors showed a unique pattern of non -incisal wear that is better described as dental corrosion. The severe loss of mineralized tissue resulted in the exposure of dentin on the lingual surface (classified as IIIb on the Eccles modified index for dental erosion; Eccles, 1979; Eccles and Jenkins, 1974) and the presence of a very thin enamel outline on the lingual surface (Figure 8). The enamel of the lingual surface of the deciduous canine and molars presented moderate to intense levels of thinning - with dentin observed under a thin layer of enamel on the lingual portion of both $\mathrm{dm}^{1}$.

In addition to this pattern of differential corrosion, the lower and upper dentition - incisors included - also presented normal occlusal wear resulting from attrition and/or abrasion compatible with Degree 2 on Molnar's scale (Molnar, 1971; Smith, 1984) (Figure 9). The symmetrical occlusal dental wear pattern was observed between tooth rows indicating normal masticatory cycles.

A scanning electron microscopy (SEM) was used to observe microwear of the lingual surface of maxillary incisors. The $\mathrm{rdi}^{1}$ and $\mathrm{rdi}^{2}$ were fixed on aluminum stubs with silver-containing glue (Electron Microscopy Sciences/SDP - Colloidal Silver Liquid) and sputter-coated with gold (Balzers SCD050 - Bal-Tec/Leica Microsystems). Teeth were examined under Sigma VP microscope (Carl Zeiss NTS Ltd) with 50X to 600X magnification. It was possible to observe on both specimens some light cross-hatched scratches resulting from masticatory abrasion (Figure 10). However, the whole analyzed surface presented wide smooth areas with exposed dentinal tubules, indicating an erosion process (Figure 11).

\section{Discussion}

Changes to bones and teeth can occur for many reasons and diagenesis is one of them. The enamel and dentine loss observed in the upper incisors of the subadult could be the result of dissolution in low-pH solutions from the burial sediment in contact with teeth. Nevertheless, Burial 2 did not have a low $\mathrm{pH}$; rather, $\mathrm{pH}$ was neutral at $6.64-7.15$ (Silva et al., 2019).

The unique pattern of dental wear found on Burial 2 of Pedra do Cachorro was clearly not related to the most common processes of occlusal attri- 


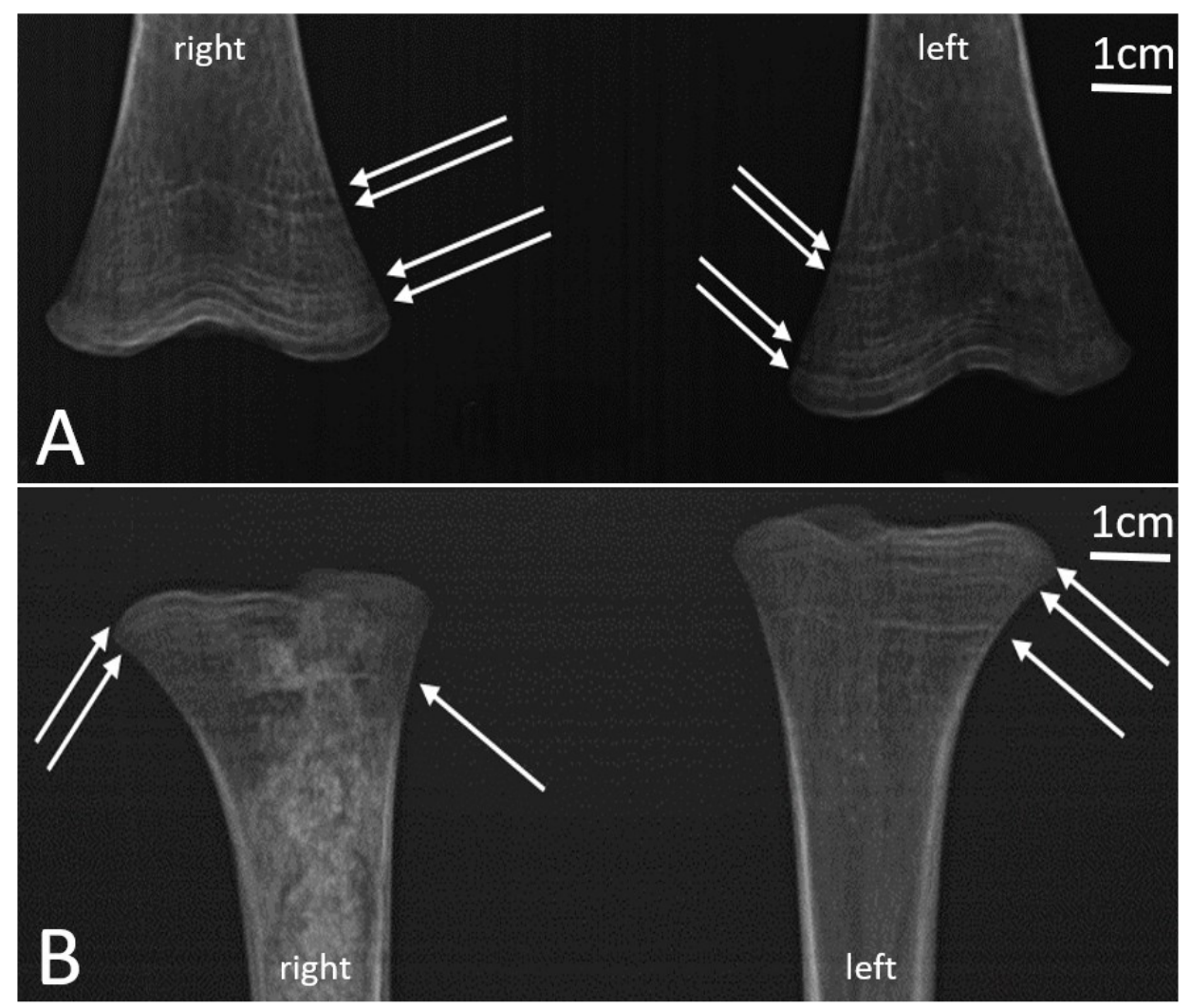

Figure 7. X-ray images of the proximal extremity of femora (A) and distal extremity of tibiae (B) showing the location of Harris lines (white arrows).
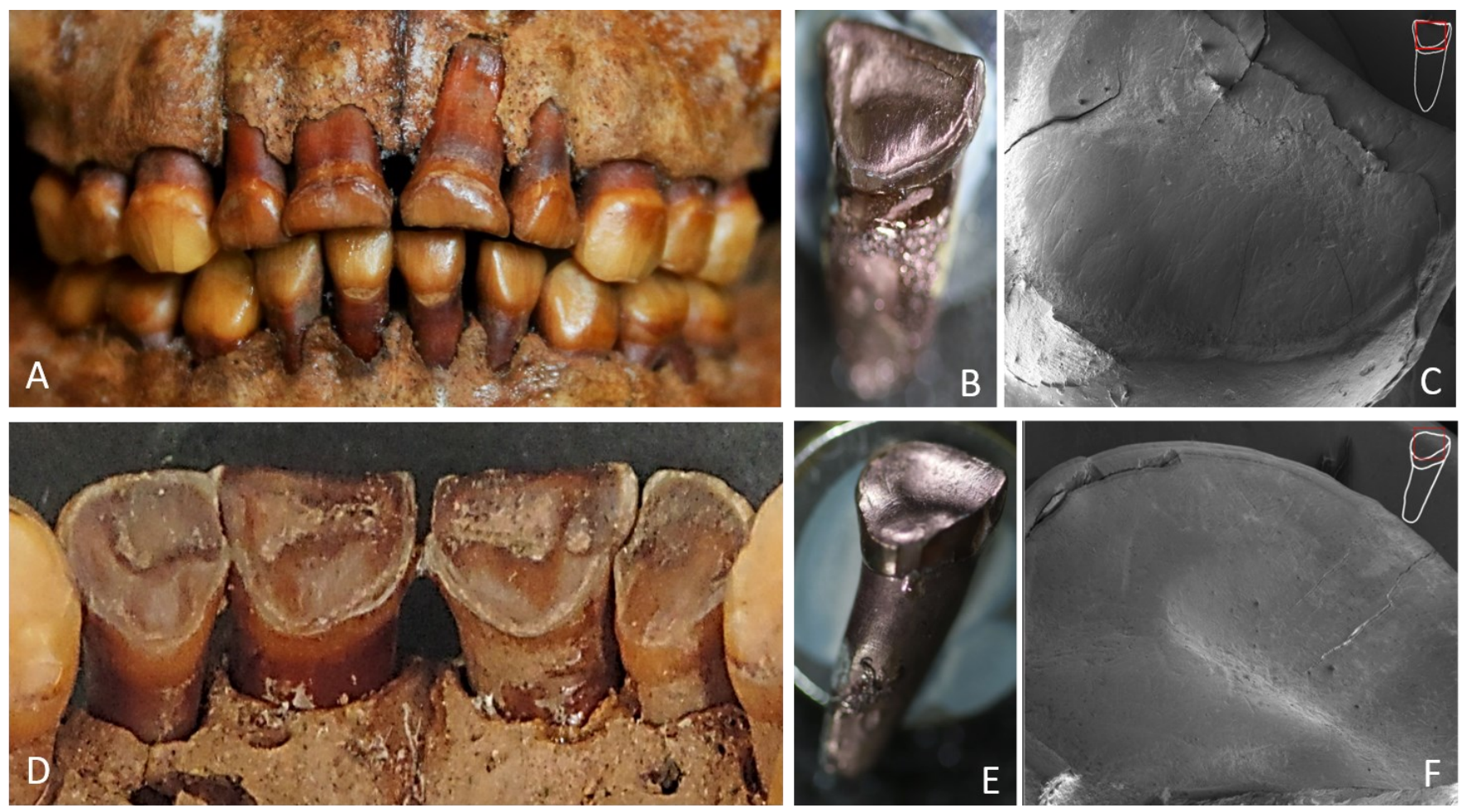

Figure 8. Detail of maxillary teeth: buccal/labial view (A) and lingual view (D) showing acid erosion on all incisors. It is possible to observe the convexities on the cervical third and the concavities on the incisal third of the lingual surface of upper incisor crowns. The $\operatorname{rdi}^{1}$ : metalized sample (B); SEM view: 47x magnification (C); rdi $^{2}$ : metalized sample (E); SEM view: 49x magnification $(\mathbf{F})$. 


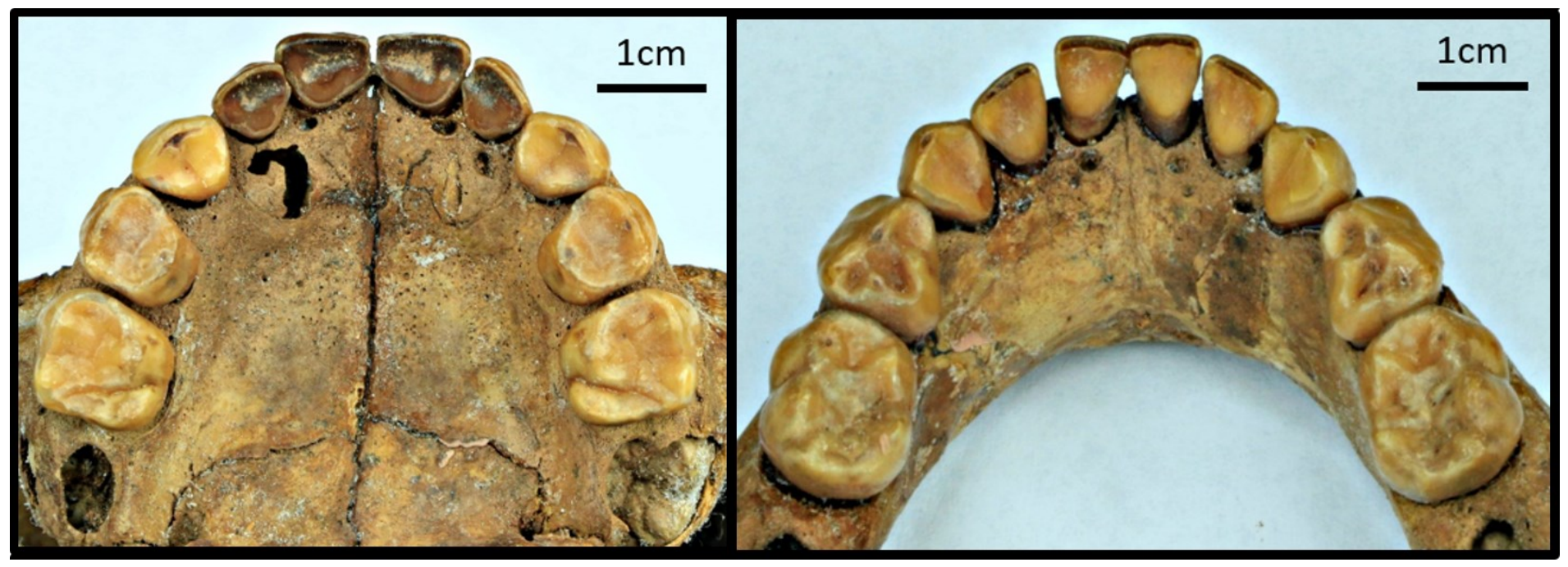

Figure 9. Maxillae and mandible from Burial 2. It is possible to observe physiological dental wear on the occlusal surfaces.
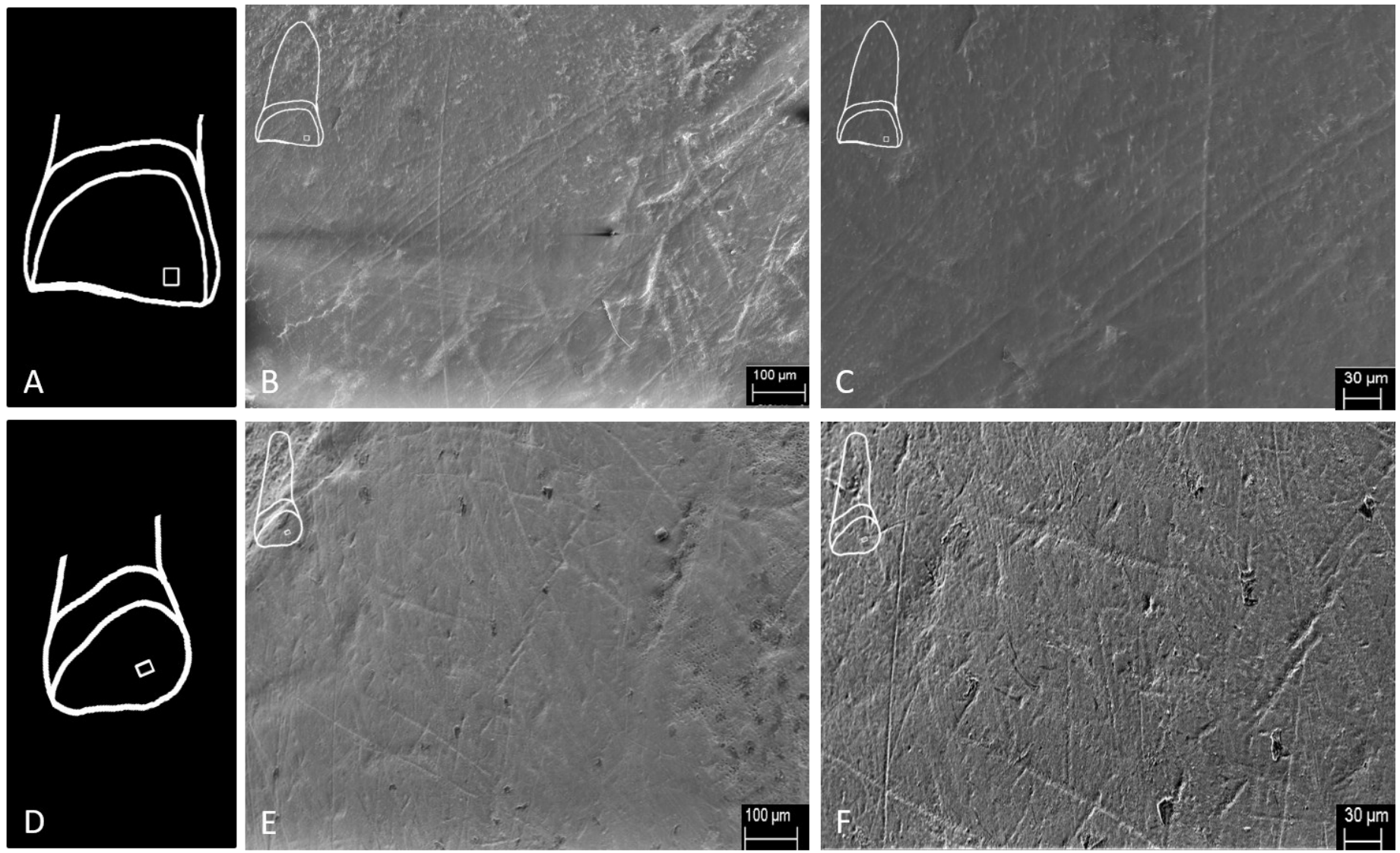

Figure 10. SEM of the lingual surface exposing a cross-hatched wear pattern of dental abrasion. Top row: drawing of $\mathrm{rdi}^{1}$ shows the location of SEM analysis (A); $\mathrm{rdi}^{1}$ SEM view: 200x magnification (B); $\mathrm{rdi}^{1}$ SEM view: 400x magnification (C). Bottom row: drawing of rdi $^{2}$ shows the location of SEM analysis (D); rdi² SEM view: 200x magnification (E); rdi ${ }^{2}$ SEM view: 400x magnification (F). 

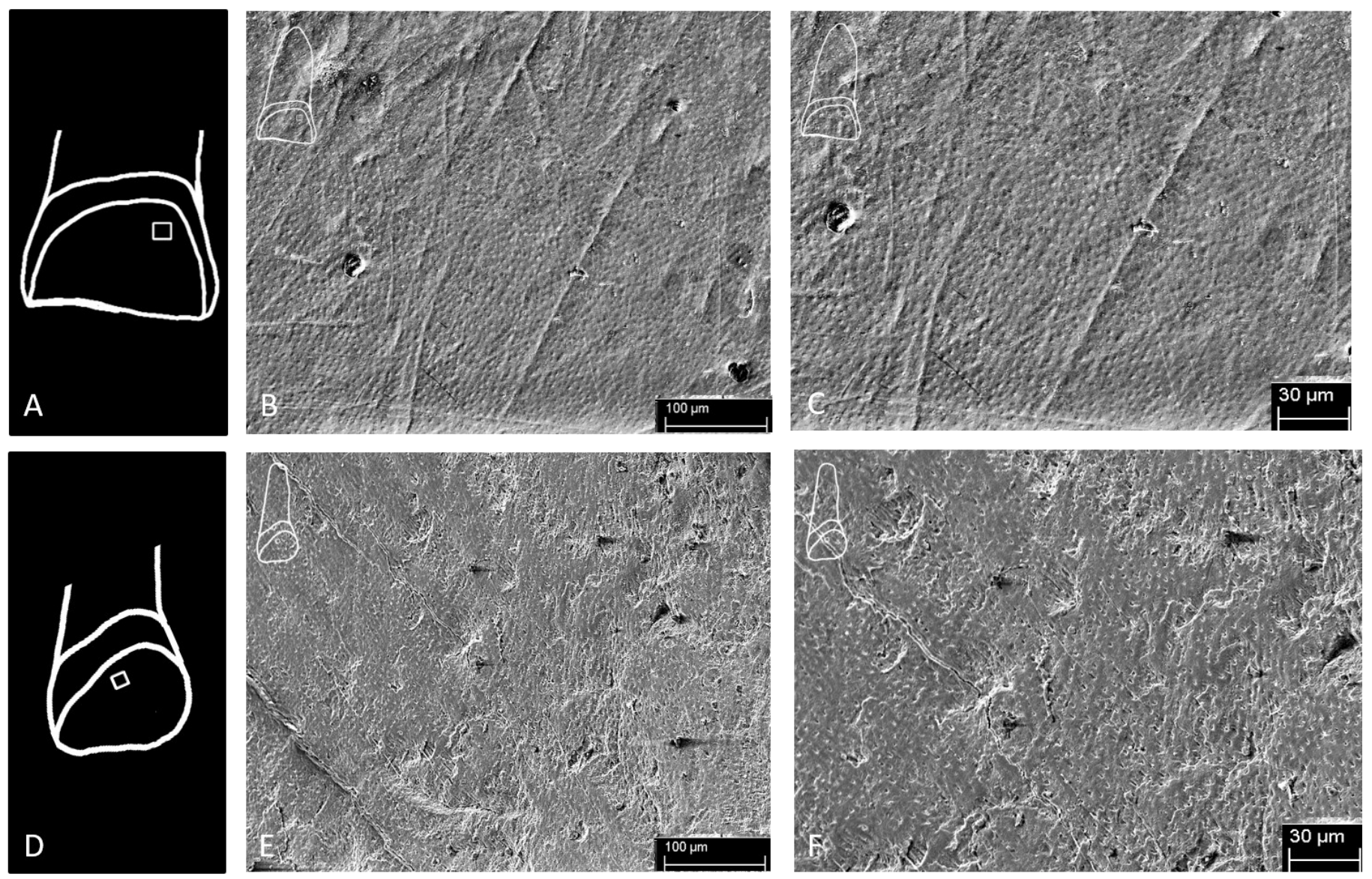

Figure 11. SEM of the lingual surface showing dentine with exposed dentinal tubules, indicative of dental corrosion.

Top row: drawing of $\mathrm{rdi}^{1}$ shows the location of SEM analysis (A); $\mathrm{rdi}^{1}$ SEM view: 400x magnification (B); $\mathrm{rdi}^{1} \mathrm{SEM}$ view: 600x magnification (C). Bottom row: drawing of $\mathrm{rdi}^{2}$ shows the location of SEM analysis (D); $\mathrm{rdi}^{2}$ SEM view: 400x magnification (E); rdi2 SEM view: 600x magnification (F).

tion resulting from masticatory cycles. Parafunctional habits provide alternative mechanisms capable of generating distinct patterns of dental wear. Bruxism, for example, results in considerable loss of mineral material. However, the abrasion angles observed in the dentition of Burial 2 were not compatible with the limited movements of the temporomandibular joint involved in bruxism (Brace and Molnar, 1967; Molnar, 1971). Alternatively, injuries or malformation of the temporomandibular joint could result in abnormal wearing of teeth. However, for Burial 2 of Pedra do Cachorro normal masticatory movement was indicated both by the perfect positioning of the upper and lower dentition, and by the presence of occlusal wear pattern compatible with children with a mixed fed/ weaned diet, or those who had started exclusively masticatory functions earlier in life (MartinezMaza et al., 2016; Moynihan, 2005; Warren et al., 2002). Additionally, the presence of a few carious lesions and no periodontal bone resorption is to be expected in a normal 3-year-old child. The child's deciduous teeth could have been exposed for a short period of time to a cariogenic diet, with or without breastfeeding, that lasted until the third year of life. This was common in other precolonial societies (Da-Gloria et al., 2017; Iida et al., 2007; Kaplan, 1996; Spielmann, 1989).

It is important to note, as mentioned above, that sex determination is imprecise, and for some authors, it is impossible to be sure of sex when analyzing sub-adult skeletons. Nevertheless, if we estimate age-at-death of this skeleton then, our analysis suggests that if the skeleton was a girl then ageat-death would have been 3.2 years, while in the case of a boy, it would have been 3.5 years (Demirjian et al., 1973). Even if we considered that Burial 2 was a girl, her long bone length was that of a 1.5 years-old. Therefore the child had a low height for her age.

The frequent use of teeth as tools for creating artifacts from vegetable fibers, leather, or bones is 
another parafunctional mechanism capable of generating wear patterns not related to the masticatory cycle. However, once again the angles of the wear facets, the macroscopic non-flat surface of superior incisors, and the absence of complementary or similar wear on the mandibular incisors described for Burial 2 of Pedra do Cachorro were not consistent with this usage (see Figure 10 and 11). It is also important to observe that Burial 2 was that of a young child, and therefore, less likely to participate in these kind of socio-cultural activities (e.g. Oliveira, 2014; Larsen et al., 1998; Molnar, 1971).

We consider that recurrent episodes of vomiting or chronic reflux were the best candidates in explaining the pattern of corrosion observed for Burial 2. The direction of the flow of gastric fluids into the mouth resulting from these conditions (posterior-anterior) are known to cause a strong and moderate/mild demineralization of the lingual surface of the anterior and posterior maxillary dentition, respectively (Bartlett et al., 2013; Lazarchik and Filler, 2000). The buccal surface of maxillary teeth is partially protected by the oral mucosa, whereas mandibular teeth are protected by the cheek and tongue during vomiting, protecting these dental surfaces from gastric fluids, as seen in Burial 2 (Linnett and Seow, 2001). In fact, abrasion and attrition may have contributed to the dental wear noted on the occlusal surface, but the evidence present on the lingual surface of the maxillary incisors shows an acidic corrosion context similar to that from clinical cases of regurgitation lesions as seen in Figure 12 (Grippo et al., 2012; Lanigan and Bartlett, 2013; Lussi et al., 2011). In both cases, the lingual surfaces presented tissue loss near the gingival margins where tooth-to-tooth contact does not occur (Robb et al., 1991b).

In addition, the SEM views strongly suggest a dental erosion scenario. Parallel scratches observed in attrition or LSAMAT cases are totally absent on $\mathrm{rdi}^{1}$ and $\mathrm{rdi}^{2}$ (see Figures 10 and 11) (Kieser et al. 2001). The microscopic images show a combination of light abrasive wear due to a normal chewing process (see Figure 10), and most of the dentine surface with exposed dentinal tubules caused by a corrosive process on the maxillary incisors of Burial 2 (see Figure 11) (Kieser et al. 2001).

Gastric disorder leading to systemic vomiting or chronic reflux can be caused by a broad range of specific conditions such as gastrointestinal inflammatory diseases, anatomical abnormalities, malignant tumors, intracranial hypertension, central nervous system infection, metabolic diseases, and toxic food intake (Katz et al., 2013; Nebel et al.,

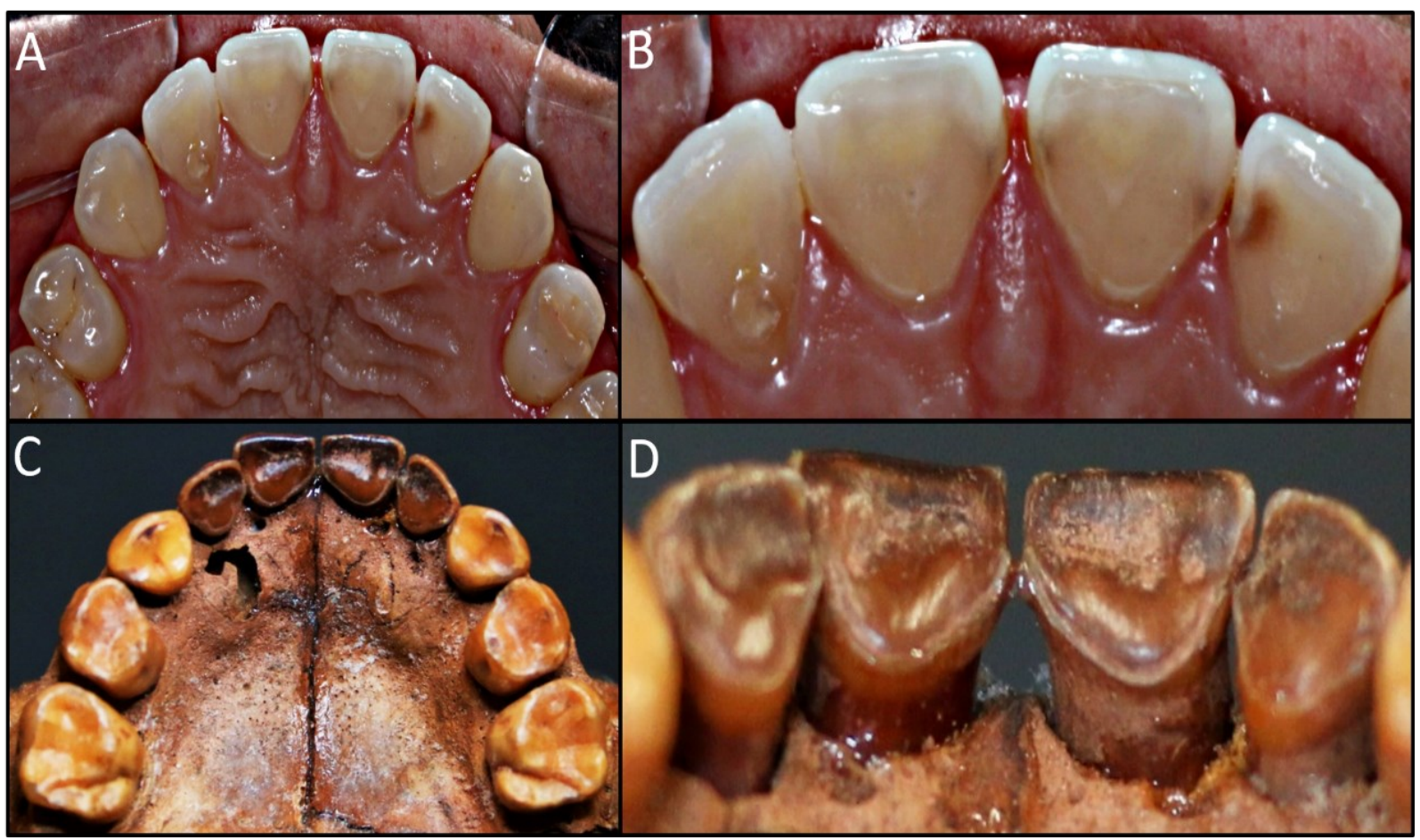

Figure 12. Comparison of the clinical case photos (above) and the archaeological case study photos (below). The upper anterior teeth of a 27-year-old female patient with lingual wear due to dental corrosion by GERD (A and B). Upper anterior teeth of the Burial 2 show very similar lesions along the lingual surface (C and $\mathbf{D})$. 
1976; Rudolph et al., 2001; Vakil et al., 2006; van Herwaarden et al., 2000; Vandenplas et al., 2009). For Burial 2 of Pedra do Cachorro the presence of LEH, Harris lines, and relatively short limbs seem to indicate that the pathological condition leading to vomiting/reflux was associated with an overall scenario of malnutrition and physiological stress (Guatelli-Steinberg et al., 2004; Oliveira and Neves, 2015; Umapathy et al., 2013; Mays, 1995). These chronic disorders could be associated with the premature death of this child (Deaton, 2008; Kielmann and McCord, 1978; Maitland et al., 2006; Onis, 2010; Rice et al., 2000; van den Broeck, 1995). It is interesting to note that standard osteological markers of metabolic distress during early childhood such as cribra orbitalia and porotic hyperostosis were not observed on this individual. Finally, our study supports the notion that physical illnesses such as gastric disorder could have been responsible for cases of dental corrosion in ancient human remains.

\section{Acknowledgments}

Rodrigo Oliveira and André Strauss wish to express their gratitude to the Department of Archaeology of UFPE for their kind invitation to analyze the bones of Burial 2 from Pedra do Cachorro-PE. Ana Solari and Sérgio F.S.M. da Silva are grateful for the financial support of the INCT-INAPAS. Ana Solari also thanks the financial support of CAPES-PNPD. André Strauss was funded by FAPESP (2017/16451-2). The authors would like to thank Humberto Faria for the beautiful photos of the skeleton presented in this article and Márcio V. Cruz for the vital technical support in microscopic analyses.

\section{REFERENCES}

Bartlett, D.W., Lussi, A., West, N.X., Bouchard, P., Sanz, M., \& Bourgeois, D. (2013). Prevalence of tooth wear on buccal and lingual surfaces and possible risk factors in young European adults. Journal of Dentistry, 41, 1007-1013.

Black, S., \& Scheuer, L. (1996). Age changes in the clavicle: from the early neonatal period to skeletal maturity. International Journal of Osteoarchaeology, 6, 425-434.

Brace, C.L., \& Molnar, S. (1967). Experimental studies in human tooth wear: I. American Journal Physical Anthropology, 27, 361-8.

Carlsson, G.E., Egermark, I., \& Magnusson, T. (2003). Predictors of bruxism, other oral parafunctions, and tooth wear over a 20-year follow -up period. Journal of Orofacial Pain, 17, 50-57.
Coupal, I., \& Sołtysiak, A. (2017). Dental erosion in archaeological human remains: A critical review of literature and proposal of a differential diagnosis protocol. Archives of Oral Biology, 84, 50-57.

Cunninghan, C., Scheuer, L., Black, S., \& Liversidge, H.M. (2016). Skeletal development and ageing, in: Cunningham, C., Scheuer, L., Black, S., Liversidge, H.M. (Eds.), Development Juvenile Osteology. Academic Press - Elsevier, London, UK, pp. 5-18.

d'Incau, E., Couture, C., \& Maureille, B. (2012). Human tooth wear in the past and the present: tribological mechanisms, scoring systems, dental and skeletal compensations. Archives of Oral Biology, 57, 214-29.

Da-Gloria, P., Oliveira, R.E., \& Neves, W.A. (2017). Dental caries at Lapa do Santo, central-eastern Brazil: An Early Holocene archaeological site. Anais da Academia Brasileira de Ciências, 89, 307316.

Deaton, A. (2008). Height, health, and inequality: the distribution of adult heights in India. American Economic Review, 98, 468-474.

Demirjian A., Goldstein H., \& Tanner J.M. (1973). A new system of dental age assessment. $\mathrm{Hu}$ man Biology, 45(2):211-27.

Deter, C.A. (2009). Gradients of occlusal wear in hunter-gatherers and agriculturalists. American Journal Physical Anthropology, 138, 247-54.

Dong, Y.M., Pearce, E.I., Yue, L., Larsen, M.J., Gao, X.J., \& Wang, J.D. (1999). Plaque $\mathrm{pH}$ and associated parameters in relation to caries. Caries Research, 33, 428-36.

Dori, I., \& Moggi-Cecchi, J. (2014). An enigmatic enamel alteration on the anterior maxillary teeth in a prehistoric North Italian population. American Journal Physical Anthropology, 154, 609 -614 .

Eccles, J.D. (1979). Dental erosion of nonindustrial origin. A clinical survey and classification. Journal of Prosthetic Dentistry, 42(6), 649-653.

Eccles, J.D., \& Jenkins, W.G. (1974). Dental erosion and diet. Journal of Dentistry, 2, 153-159.

Ekstrand, J., \& Oliveby, A. (1999). Fluoride in the oral environment. Acta Odontologica Scandica, 57, 330-3.

Gindhart, \& P.S. (1973). Growth standards for the tibia and radius in children aged one month through eighteen years. American Journal Physical Anthropology, 39, 41-48.

Grippo, J.O., Simring, M., \& Coleman, T.A. (2012). Abfraction, abrasion, biocorrosion, and the enigma of noncarious cervical lesions: A 20- 
year perspective. Journal of Esthetic and Restorative Dentistry, 24, 10-23.

Guatelli-Steinberg, D., Larsen, C.S., \& Hutchinson. D.L. (2004). Prevalence and the duration of linear enamel hypoplasia: a comparative study of Neandertals and Inuit foragers. Journal of Human Evolution, 47, 65-84.

Gudmundsson, K., Kristleifsson, G., Theodors, \& A., Holbrook, W.P. (1995). Tooth erosion, gastroesophageal reflux, and salivary buffer capacity. Oral Surgery, Oral Medicine, Oral Pathology, and Oral Radiology, 79, 185-189.

Hillson, S. (2008). The Current State of Dental Decay, in: Irish, J.D., Nelson, G.C. (Eds.), Technique and Application in Dental Anthropology. Cambridge University Press, Cambridge, United Kingdom, pp. 111-135.

Honório, H.M., Rios, D., Santos, C.F., Magalhães, A.C., Buzalaf, M.A.R., \& Machado, M.A.A.M. (2008). Effects of erosive, cariogenic or combined erosive/cariogenic challenges on human enamel: an in situ/ex vivo study. Caries Research, 42, 454-9.

Iida, H., Auinger, P., Billings, R.J., \& Weitzman, M. (2007). Association between infant breastfeeding and early childhood caries in the United States. Pediatrics, 120, e944-52.

Irish, J.D., \& Turner, C.G. More Lingual Surface Attrition of the Maxillary Anterior Teeth in American Indians: Prehistoric Panamanians. (1987). American Journal of Physical Anthropology, 73, 209-213.

Järvinen, V.K., Rytömaa, I.I., \& Heinonen, O.P. (1991). Risk factors in dental erosion. Journal of Dentistry Research, 70, 942-947.

Kaplan, H. (1996). A theory of fertility and parental investment in traditional and modern human societies. American Journal Physical Anthropology, 101, 91-135.

Katz, P.O., Gerson, L.B., \& Vela, M.F. (2013). Guidelines for the diagnosis and management of gastroesophageal reflux disease. American Journal of Gastroenterology, 108, 308-28; quiz 329.

Kielmann, A.A., \& McCord, C. (1978). Weight-forage as index of risk of death in children. Lancet, 1247-1250.

Kieser, J.A., Dennison, K.J., Kaidonis, J.A., Huang, D., \& Herbison, P.G.P., Tayles, N.G. (2001). Patterns of Dental Wear in the Early Maori Dentition. International Journal of Osteoarchaeology, 11, 206-217.

Lanigan, L.T., \& Bartlett, D.W. (2013). Tooth wear with an erosive component in a Mediaeval Ice- land population. Archives of Oral Biology, 58, 1450-1456.

Larsen, C.S., Teaford, M.F., \& Sandford, M.K. (1998). Teeth as tools at Tutu: Extramasticatory behavior in prehistoric St. Thomas, U.S. Virgin Islands, in: Lukacs, J.R. (Ed.), Human Dental Development, Morphology, and Pathology: A tribute to Albert A. Dahlberg. University of Oregon Anthropological Papers, Oregon - USA, pp. 401-420.

Larsen, M.J. (2008). Erosion of the Teeth, in: Fejerskov, O., Kidd, E.A.M., Nyvad, B., Baelum, V. (Eds.), Dental Caries: The Disease and its Clinical Management. Blackwell Munksgaard Publishing Ltda, Oxford - United Kingdom, pp. 233248.

Lazarchik, D.A., \& Filler, S.J. (2000). Dental erosion: predominant oral lesion in gastroesophageal reflux disease. American Journal of Gastroenterology, 95, S33-8.

Linnett, V., \& Seow, K. (2001). Dental erosion in children: A literature review. Pediatric Dentistry, 23, 37-43.

Lucas, P.W., \& Omar, R. (2012). Damaged! A new overview of dental wear. Archives of Oral Biology, 57, 211-3.

Lussi, A., Schlueter, N., Rakhmatullina, \& E., Ganss, C. (2011). Dental erosion: An overview with emphasis on chemical and histopathological aspects. Caries Research, 45 Suppl 1, 2-12.

Maitland, K., Berkley, J.A., Shebbe, M., Peshu, N., English, M., \& Newton, C.R.J.C. (2006). Children with severe malnutrition: Can those at highest risk of death be identified with the WHO protocol? PLoS Medicine, 3, 2431-2439.

Manfredini, D., \& Lobbezoo, F. (2009). Role of psychosocial factors in the etiology of bruxism. Journal of Orofacial Pain, 23, 153-166.

Maresh, M.M. (1970). Measurements from roentgenograms, in: McCammon, R.W. (Ed.), Human and Growth Development. Springfield IL: Thomas, Charles C, pp. 157-200.

Martinez-Maza, C., Freidline, S.E., Strauss, A., \& Nieto-Diaz, M. (2016). Bone growth dynamics of the facial skeleton and mandible in Gorilla gorilla and Pan troglodytes. Evolutionary Biology, 43, 60-80.

Mays, S. (1995) - The Relationship between Harris Lines and other Aspects of Skeletal Development in Adults and Juveniles. Journal of Archaeological Science, 22, 511-520.

Mays, S., \& Cox, M. (2000). Sex determination in skeletal remains, in: Cox, M., Mays, S., Human Osteology in Archaeology and Forensic Science. 
Cambridge: Cambridge University Press, pp. 117-130.

Moazzez, R., Bartlett, D., \& Anggiansah, A. (2004). Dental erosion, gastro-esophageal reflux disease and saliva: How are they related? Journal of Dentistry, 32, 489-494.

Molnar, P. (2008). Dental wear and oral pathology: possible evidence and consequences of habitual use of teeth in a Swedish Neolithic sample. American Journal Physical Anthropology, 136, 423 -31 .

Molnar, S. (1971). Human tooth function and cultural variability. American Journal Physical Anthropology, 34, 175-190.

Morimoto, S., Sesma, N., Agra, C.M., GuedesPinto, A.C., \& Hojo, K.Y. (2014). Dental Erosion: etiology, mechanisms and implications. Journal of Biodentistry and Biomaterials, 4, 6-23.

Moynihan, P.J. (2005). The role of diet and nutrition in the etiology and prevention of oral diseases. Bulletin of World Health Organization, 83, 694-9.

Nascimento, M.M., Dilbone, D.A., Pereira, P.N., Duarte, W.R., Geraldeli, S., \& Delgado, A.J. (2016). Abfraction lesions: etiology, diagnosis, and treatment options. Clinical, Cosmetic and Investigational Dentistry, 8, 79-87.

Nebel, O.T., Fornes, M.F., \& Castell, D.O. (1976). Symptomatic gastroesophageal reflux: Incidence and precipitating factors. The American Journal of Digestive Diseases, 21, 953-956.

Oliveira, R.E. (2014). Prevalencia de patologías orales en los oasis de San Pedro de Atacama, first. ed. Publicia - OmniScriptum GmbH \& CO Saabrücken, Deutschland, Saarbrücken, Deutshland.

Oliveira, R.E., \& Neves, W.A. (2015). Oral health in prehistoric San Pedro de Atacama oases, Northern Chile. HOMO - Journal of Comparative Human Biology, 66, 492-507.

Onis, M. (2010). Measuring nutritional status in relation to mortality. World Health Organization: WHO, 10, 1271-1274.

Pavone, B.W. (1985). Bruxism and its effect on the natural teeth. Journal of Prosthetic Dentistry, 53, 692-696.

Rice, A.L., Sacco, L., Hyder, A., \& Black, R.E. T (2000). Malnutrition as an underlying cause of childhood deaths associated with infectious diseases in developing countries. Bulletin of the World Health Organization, 78, 1207-1221.

Robb, N.D., Cruwys, E., \& Smith, B.G.N. (1991a). Regurgitation erosion as a possible cause pf tooth wear in ancient British populations. Archives of Oral Biology, 36, 595-602.

Robb, N.D., Cruwys, E., \& Smith, B.G.N. (1991b). Is "Lingual Surface Attrition of the Maxillary Teeth (LSAMAT)" Caused by Dental Erosion? American Journal Physical Anthropology, 85, 345351

Rudolph, C.D., Mazur, L.J., Liptak, G.S., Baker, R.D., Boyle, J.T., Colletti, R.B., Gerson, W.T., \& Werlin, S.L. (2001). Guidelines for evaluation and treatment of gastroesophageal reflux in infants and children: Recommendations of the North American Society for Pediatric Gastroenterology and Nutrition. Journal of Pediatric Gastroenterology and Nutrition, 32, S1-S31.

Scheid, R.C., \& Weiss, G. (2012). Dental anomalies, in: Scheid, R.C., Weiss, G. (Eds.), Woelfel's Dental Anatomy. Lippincott Williams \& Wilkins, Philadelphia - USA, pp. 323-344.

Schutkowski, H. (1993). Sex determination of infant and juvenile skeletons: I. Morphognostic features. American Journal Physical Anthropology, 90, 199-205.

Smith, B.H. (1984). Patterns of molar wear in hunter-gatherers and agriculturalists. American Journal Physical Anthropology, 63, 39-56.

Silva, S.F.S.M., Ghetti, N.C., \& Solari, A. (2019). Medição de Ph em Sedimentos Associados aos Ossos de Esqueleto de Criança, Sepultamento 2, Sítio Pedra Do Cachorro, Buíque - Pe, Brasil. CLIO - Arqueológica, 2, 1-6. (In press).

Solari, A., Silva, S.F.M.S., \& Mello, S. (2015). Estudo de caso sobre indicadores bioarqueológicos de práticas mortuárias complexas em esqueleto humano coletado no abrigo Pedra do Cachorro, Buíque, PE. CLIO - Arqueológica, 30, 99-119.

Solari, A., Alves-Pereira, A., Sá Espinola, C., Martin, G., Pacheco da Costa, I., \& Serafim Monteiro da Silva, S.F. (2016). Escavações arqueológicas no abrigo funerário Pedra Do Cachorro, Buíque - Pe. CLIO - Arqueológica, 31, 105-135.

Spielmann, K.A. (1989). A Review: Dietary restrictions on hunter-gatherer women and the implications for fertility and infant mortality. Human Ecology, 17, 321-345.

urner, C.G., \& Machado, L.M.C. (1983). A New Dental Wear Pattern and Evidence for High Carbohydrate Consumption in a Brazilian Archaic Skeletal Population. American Journal Physical Anthropology, 61:125-130.

Ubelaker, D.H. (1989). Human Skeletal Remains: Excavation, Analysis and Interpretation, Second ed. 
Taraxacum, Washington, DC - USA.

Umapathy, T., Jayam, C., Yogish, P., Yogish, A., \& Bandlapalli, A. (2013). Linear Enamel Hypoplasia. Journal of Indian Academy of Oral Medicine and Radiology, 25(2), 153-156.

Vakil, N., Van Zanten, S.V., Kahrilas, P., Dent, J., Jones, R., Bianchi, L.K., \& Cesario, K.B. (2006). The Montreal definition and classification of gastroesophageal reflux disease: A global evidence-based consensus. American Journal of Gastroenterology, 101, 1900-1920.

Van't Spijker, A., Rodriguez, J.M., Kreulen, C.M., Bronkhorst, E.M., Bartlett, D.W., \& Creugers, N.H.J. (2009). Prevalence of tooth wear in adults. Int. J. Prosthodont. 22, 35-42.

van den Broeck, J. (1995). Malnutrition and mortality. Journal of the Royal Society of Medicine, 88, 487-90.

van Herwaarden, M.A., Samsom, M., \& Smout, A.J.P.M. (2000). Excess gastroesophageal reflux in patients with hiatus hernia is caused by mechanisms other than transient LES relaxations. Gastroenterology, 119, 1439-1446.

Vandenplas, Y., Rudolph, C.D., Lorenzo, C., Hassall, E., Liptak, G., Mazur, L., Sondheimer, J., Staiano, A., Thomson, M., Veereman-Wauters, G., \& Wenzl, T.G. (2009). Pediatric gastroesophageal reflux clinical practice guidelines: joint recommendations of the North American Society for Pediatric Gastroenterology, Hepatology, and Nutrition (NASPGHAN) and the European Society for Pediatric Gastroenterology, Hepatology, and Nutrition (ESPGHAN). Journal of Pediatric Gastroenterology and Nutrition, 49, 498-547.

Warren, J.J., Yonezu, T., Bishara, S.E., \& Ortho, D. (2002). Tooth wear patterns in the deciduous dentition. American Journal of Orthodontics and Dentofacial Orthopedics, 122, 614-618.

Waters-Rist, A., Bazaliiskii, V.I., Weber, A., Goriunova, O.I., \& Katzenberg, M.A. (2010). Activity-induced dental modification in Holocene Siberian hunter-fisher-gatherers. American Journal Physical Anthropology, 143, 266-78. 